Article

\title{
How Do Populist Voters Rate Their Political Leaders? Comparing Citizen Assessments in Three Jurisdictions
}

\author{
Gerard Seijts ${ }^{1}$ and Cristine de Clercy ${ }^{2, *}$ \\ ${ }^{1}$ Ivey Business School, Western University, London, N6G 0N1, Canada; E-Mail: gseijts@ivey.ca \\ 2 Department of Political Science, Western University, London, N6G 2N6, Canada; E-Mail: c.declercy@uwo.ca \\ * Corresponding author
}

Submitted: 3 October 2019 | Accepted: 19 January 2020 | Published: 5 March 2020

\begin{abstract}
Drawing from the field of management studies, we explore how a sample of voters in the United States, Canada, and the United Kingdom use a leader character framework to judge political leadership. We ask, how do voters actually assess the character of their current leaders? And, in light of the populist zeitgeist, do people who hold a populist attitude differ markedly in how they judge the character of political leaders? Our results show that voters generally consider character important. However, voters who lean toward populism believe character matters less in political leadership than individuals who scored low on the populism indicator. This durable difference merits more exploration in a political context marked by populism. Our findings about the factors that influence vote choice contribute to this conversation and to extant research that reports that some voters pay greater attention to leader characteristics than do others.
\end{abstract}

\section{Keywords}

Canada; leaders; leadership; politics; populism; United Kingdom; United States

Issue

This article is part of the issue "Leadership, Populism, and Power" edited by Cristine de Clercy (Western University, Canada).

(C) 2020 by the authors; licensee Cogitatio (Lisbon, Portugal). This article is licensed under a Creative Commons Attribution 4.0 International License (CC BY).

\section{Introduction}

Writing about political parties in Western Europe, Cas Mudde notes that parties on the right of the political spectrum enjoy a favourable discursive environment (2013, p. 15). Transformation of the mass media, electoral trends, economic insecurity, and inter-party competition are among key factors encouraging a context of soft populism where even mainstream parties now feature populist language and themes in their communications. Mudde suggests many of the policies pursued by popular radical right parties reflect existing attitudes and policy preferences among democratic voters. So, rather than being responsible for initiating these preferences, these sorts of parties simply benefit from them (Mudde, 2013, p. 1).

While the debate continues over whether populist parties are growing more powerful or are merely a reflec- tion of the modern zeitgeist, Mudde's comments underscore that populism is found in every democratic polity. With growing populism, the role of character in leadership selection has become increasingly relevant in politics, as was underscored, for example, in the events surrounding the 2016 presidential campaign, which brought Donald Trump to the White House, and the subsequent controversies that have marred Trump's presidency. As students of leadership, we probe in this study how citizens of voting age in Canada, the United Kingdom (UK), and the United States (US) judge the character of their political leaders. Given the current populist context, we comparatively examine whether populist voters are distinct in their assessment of character.

In exploring the facets of character, we draw from the field of management studies to apply a widely-used framework to the study of political behaviour. We explored our research questions by means of an online 
opinion survey administered in Canada, the US, and the UK in the fall of 2018. The survey instrument was designed to address four research questions: Does character matter to voters? Are all eleven dimensions that comprise the leader character framework considered essential for political leadership? How do voters actually assess the character of their current leaders? And do voters who hold a populist attitude differ markedly in how they judge the character of political leaders?

We begin by reviewing the literature concerning the study of political leaders and the perceived importance of character. Then, we introduce a new framework for character evaluation that has been developed and validated by scholars working in management studies and employed in research on organizational leadership. Finally, we summarize the study's methodology, describe the main findings gleaned from the survey and offer a brief conclusion.

\section{Literature Review}

Because prime ministers and presidents sit at the apex of national politics, there are several ways to probe the leader-follower connection. An enduring approach separates a leader's qualities into two broad domains: competence and character (Crossan, Seijts, \& Gandz, 2016, pp. 3-4; see also Johnston, 2002, p. 166). There is, however, little agreement on what exactly constitutes character and how it is best measured or indicated. Some definitions are narrow, focusing on a single aspect of character, such as a leader's trustworthiness. Other scholars understand character to be a part of a large bundle of qualities that may include a variety of perceived attributes, including decisiveness, youthfulness, and toughness (King, 2002, pp. 7-9). To survey the literature's parameters and its comparative depth, we begin by briefly discussing pertinent works in each of the three countries under study.

In the US, there is a longstanding tradition of emphasizing the role of leader character in politics. A key figure is James D. Barber, who helpfully defined character as "the way the president orients himself toward life-not for the moment, but enduringly" (1972, p. 282). Barber's work was the first to press the study of presidential character beyond historical case studies of individuals (for later examples, see Greenstein, 1975; Hinck, 1993). Kinder, Peters, Abelson, and Fiske (1980, p. 330) conclude that citizens formulate prototypes about what defines an exemplary president, including personality traits and behavioural expectations. Pfiffner (2003, p. 7) concludes, "Americans agree that presidential character is important-just as or more important than intellect, organizational ability, television presence, and effectiveness in public speaking." At the same time, other analysts find that the actual effects of candidates' personal qualities upon vote choice in American presidential elections are negligible (e.g., Miller \& Shanks, 1996).

In contrast to the American literature, there is much less attention paid in Canada to leader character. Only a handful of studies concern character and how voters assess it (Ballard \& Suedfeld, 1988; Courtney, 1976). The most continuous set of information across time about how voters perceive aspects of political leadership appears in the Canadian election studies series. Scholars here investigate how key parameters such as region, religion, and socio-economic status influence vote choice (e.g., Clarke, Kornberg, MacLeod, \& Scotto, 2005). Key studies find information about political leaders, such as their province of origin or debate performance, contributes to explaining how voters make their choice (see Nadeau \& Blais, 1995, p. 216). Johnston (2002, p. 179) concludes that while the net effects are small, Canadian voters do take leaders' personalities into account. However, the analysis of character tends to focus narrowly on single measures across several cases, and these measures are limited to a handful of items. The battery of items changes across federal election surveys, and often character is indicated simply by asking how much voters like particular leaders (Bittner, 2011; Canadian Election Study, 2015; Johnston, 2002, pp. 166-167).

The study of leader character among British academics more closely resembles the Canadian literature than the American. British study is dominated by attention to the institutions surrounding leaders (Bennister, 2008, pp. 336-337). Some scholars have drawn from American studies of leader personality to inform their understanding. Theakston, for example, employs the work of Greenstein to analyse the leadership of prime minister Gordon Brown (Theakston, 2011; see also Mansfield, 2004). Some insight into how scholars consider character and its perception by followers can be discerned in national election studies, such as the British Election Study (BES), which has been conducted since 1964. Comparing the 2015 and 2017 general elections, for example, the BES team probed how changing the party leader impacted how voters felt about the party (Johnston, Hartman, \& Pattie, 2019). The BES study's core questionnaire focuses mainly on probing the likeability of leaders and does not engage the broader concept of character. As in the American case, British analysts disagree about the net effect of party leader characteristics on election outcomes, with many studies reporting mild to moderate influence (Bartle \& Crewe, 2002, pp. 74-78; Garzia, 2011).

The comparative study of leader character and vote preference is a rather underdeveloped area of inquiry. King (2002, p. 3) notes that while the issue of leaders' personalities is an important one, "political scientists and other social scientists, especially outside of the United States, have had relatively little to say on the subject." King published the first comparative volume ever devoted to the subject in 2002. In 2011, Aarts, Blais, and Schmitt edited a book that used election surveys across fifty years to probe the effect of political leaders on vote choice in nine democracies. Examining what he called the personalization of politics in eight democratic countries, Garzia (2011) suggested scholars need to pay much more attention to the interaction between a leader's per- 
sonality and contextual factors such as the ideological orientation of the voters. He notes that a number of studies concur that right-wing voters are much more likely to vote on the basis of leader personality (Garzia, 2011, p. 706). In 2015, Costa Lobo and Curtice edited a comprehensive collection on The Role of Leader Evaluations in Democratic Elections. Covering three decades of elections and leaders in thirty-four new and established democracies, the most pertinent case for our purposes is Beck and Nadeau's (2015) examination, which concludes that leader image matters a great deal in the case of French presidential elections (Costa Lobo \& Curtice, 2015, pp. 169-170). Like its counterparts, this study is somewhat constrained by its reliance on election survey data and the narrow operationalization of character that such surveys typically employ.

Because the concept of populism necessarily involves elite-mass relationships, leaders are a frequent subject of attention. De la Torre, for example, references the role of leaders and the effects of leadership throughout his analysis of populism in Latin America, a region with a significant populist tradition (de la Torre, 2017). Other analysts aim to understand how voter attitudes predict the likelihood of supporting a populist, radical right party. For example, Bos, Sheets, and Boomgaarden report that implicit attitudes matter much more for ideologically moderate Dutch voters than for more extreme voters (2018, p. 80). Several recent studies broadly engage how populists respond to their leaders. Many of these studies, however, focus on the role of discursive environments or social media technology as key in linking populists to leaders (see Muis, 2015; Stockemer \& Barisione, 2017).

There are only a handful of empirical studies directly examining how citizens perceive the character of populist politicians. This is puzzling to us owing to the view that "a defining feature of populism is its reliance on strong leaders who are able to mobilize the masses" (Mudde, 2017, p. 62). There are two main approaches that could be used to address this gap in the literature. One draws from Max Weber's work and examines the role of charismatic bonds between leaders and their followers (e.g., Meret, 2015). The second approach focuses on how modern media shapes, and is shaped by, populist leaders (e.g., van den Pas, de Vries, \& van den Brug, 2011). In line with our approach, a few authors examine the connection between perceptions of a politician's character and citizen support (see Bakker, Rooduijn, \& Schumacher, 2016). However, these analyses are rather narrow in scope, and no studies to date employ a robust, theory-driven framework that guides leadership research in focusing on the character of political leaders and voter perceptions.

In sum, as Blais wrote a decade ago, there remains surprisingly little systematic comparative analysis of the impact of leaders on vote choice across countries (2011, p. 4). Our study aims to inform some of the gaps in the extant literatures by using a comprehensive leader character framework drawn from the field of management studies to examine how populist and non-populist voters in three countries adjudicate the character of their political leaders. Our character framework, as described in the next section, is richer and more integrated than the single indicators for character used in almost all of the studies described above. Moreover, and as discussed below, we are not reliant on data from election survey studies and so our analysis is significantly more comprehensive and comparable than many existing analyses of leader effects on citizen behaviour.

\section{The Leader Character Framework and Research Questions}

Character has attracted significant attention in the field of management studies. Many leadership scholars who examine the effect of character on decision-making and subsequent action align their work with virtuous character. For example, Crossan et al. (2016) explained that character is an amalgam of virtues, personality traits, and values that enable human excellence and sustained performance. Virtues are situationally-appropriate behaviours, such as temperance and humanity, that are widely considered by individuals as emblematic of good leadership in that they contribute to the well-being of individuals and societies. Some of these virtues are personality traits, such as conscientiousness and resiliency, which are relatively stable dispositional variables. Lastly, some of the virtues operate as values, such as being equitable. Values act as deep-seated beliefs people hold about what is morally right or wrong.

Some virtues may be personality traits, but character and personality traits are not equivalent. There are important differences between these constructs (Seijts, Byrne, Crossan, \& Gandz, 2019). First, character is anchored in virtuous behaviours and can be learned, as opposed to personality traits, which are relatively stable and, importantly, mostly agnostic to virtue (Wright \& Huang, 2008). A person's character-driven behaviours may change due to deliberate practice, the effects of context or neglect and, sometimes, because of some intense, crucible experience (Byrne, Crossan, \& Seijts, 2018). Second, character addresses strengths and deficiencies whereas personality traits just are as they are. For example, we do not talk about a good or bad extrovert; however, we do emphasize strengths and deficiencies in humanity or temperance.

Crossan, Seijts, and their colleagues conducted a series of qualitative and quantitative studies involving over 2,500 leaders from the public, private, and not-for-profit sectors, which led to the development and validation of the leader character framework shown in Figure 1 (Crossan et al., 2016, 2017). Their research was specifically aimed at enhancing the legitimacy and, hence, acceptance of character into mainstream organizational practices, as well as to develop a clear, unambiguous vocabulary with which leaders can address characterrelated issues in the workplace. Crossan et al. (2016) de- 


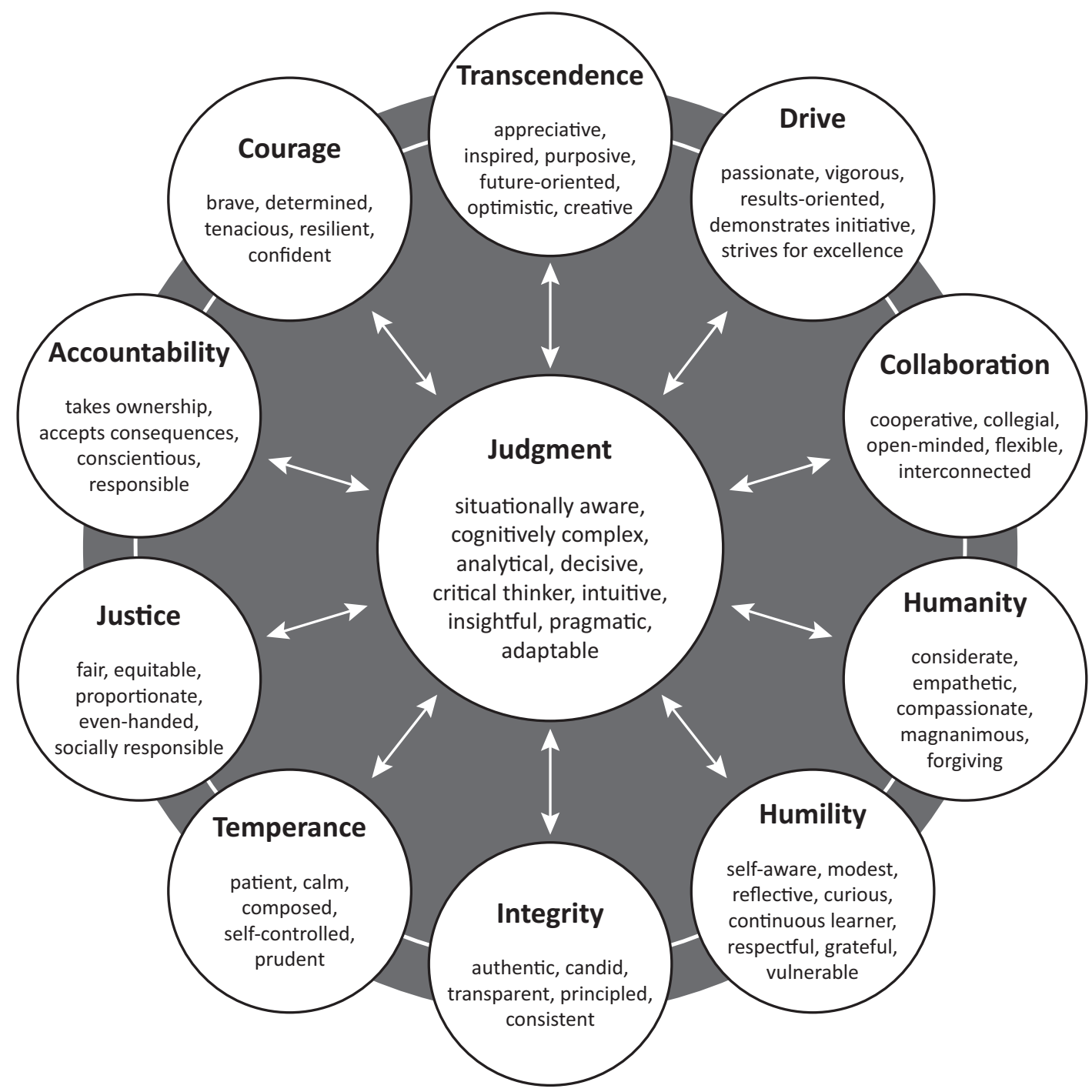

Figure 1. Leader character dimensions and associated character elements.

veloped a character diagnostic structured in both selfadministered and 360-degree formats for use in organizations in the public, private, and not-for-profit sectors. Because the diagnostic can be used in the public sector, we adopted the framework for our study.

The framework indicates that there are eleven unique dimensions of character that-independently and interactively-influence individual, team, and organizational outcomes (see Table 1 for a description of the leader character dimensions). Crossan et al. (2017) also identified 60-plus character elements that are illustrative of the character dimensions. They posit that each of the elements has an impact on the strength of the character dimension, although their impact may not be equal.

The framework in Figure 1 communicates several important features. First, the positioning of judgment in the centre is consistent with Aristotelian thinking. Aristotle argued that practical wisdom-which Crossan et al. (2017) labelled judgment-is the outcome of the application of the virtues in situationally appropriate ways. Leadership is always context-dependent such that the wise leader understands when it is appropriate to demonstrate humility and when to be assertive; when to encourage collaboration and foster engagement and when to be more directive; and so on. For example, President John F. Kennedy showed good judgment in the handling of the 1962 Cuban missile crisis, in part because he was able to activate the character dimensions of temperance, courage, humility, accountability, and drive when he truly needed them.

Second, it is essential to consider the interconnections between the character dimensions. This is because some behaviours that one might consider to be virtuous may actually operate as vices when not supported by other dimensions of character. For example, Rubenzer explained that President Jimmy Carter scored very high on achievement-striving (or drive). He was in the top one percent of all former presidents (see the interview in Dingfelder, 2004). However, his lack of assertivenessparticularly his lack of tenaciousness or resiliency (see Figure 1)-did not support the full activation of his drive, which would be considered a flaw in his leadership. 
Table 1. Dimensions for leader character.

Judgment Makes sound decisions in a timely manner based on relevant information and critical analysis of facts. Appreciates the broader context when reaching decisions. Shows flexibility when confronted with new information or situations. Has an implicit sense of the best way to proceed. Sees into the heart of challenging issues. Reasons effectively in uncertain or ambiguous situations.

Courage Does the right thing even though it may be unpopular, actively discouraged or result in a negative personal outcome. Shows an unrelenting determination, confidence, and perseverance in confronting difficult situations. Rebounds quickly from setbacks.

Drive Strives for excellence. Has a strong desire to succeed. Tackles problems with a sense of urgency. Approaches challenges with energy and passion.

Collaboration Values and actively supports development and maintenance of positive relationships among people. Encourages open dialogue and does not react defensively when challenged. Is able to connect with others at a fundamental level, in a way that fosters the productive sharing of ideas. Recognizes that what happens to someone, somewhere, can affect all.

Integrity Holds oneself to a high moral standard and behaves consistently with ethical standards, even in difficult situations. Is seen by others as behaving in a way that is consistent with personal values. Behaves consistently with organizational policies and practices.

Temperance Conducts oneself in a calm, composed manner. Maintains the ability to think clearly and responds reasonably in tense situations. Completes work and solves problems in a thoughtful, careful manner. Resists excesses and stays grounded.

Accountability Willingly accepts responsibility for decisions and actions. Is willing to step up and take ownership of challenging issues. Reliably delivers on expectations. Can be counted on in tough situations.

Justice Strives to ensure that individuals are treated fairly and that consequences are commensurate with contributions. Remains objective and keeps personal biases to a minimum when making decisions. Provides others with the opportunity to voice their opinions on processes and procedures. Provides timely, specific, and candid explanations for decisions. Seeks to redress wrongdoings inside and outside the organization.

Humility Lets accomplishments speak for themselves. Acknowledges limitations. Understands the importance of thoughtful examination of one's own opinions and ideas. Embraces opportunities for personal growth and development. Does not consider oneself to be more important or special than others. Is respectful of others. Understands and appreciates others' strengths and contributions.

Humanity Demonstrates genuine concern and care for others. Appreciates and identifies with others' values, feelings and beliefs. Has a capacity to forgive and not hold grudges. Understands that people are fallible and offers opportunities for individuals to learn from their mistakes.

Transcendence Draws inspiration from excellence or appreciation of beauty in such areas as sports, music, arts, and design. Sees possibility where others do not. Has an expansive view of things both in terms of taking into account the long term and broad factors. Demonstrates a sense of purpose in life.

The framework developed by Crossan and her colleagues (2017) proposes that, at its most basic, leader character is a highly complex network of correlated constructs (dimensions and elements) that affect decisionmaking and subsequent action and, hence, none of the leader character dimensions should be considered in isolation because a virtue can easily turn into a vice.

The contours of the literatures discussed above helped to shape and inform our study of how citizens adjudicate leader character. We focus on four research questions: Does character matter to voters? Are all eleven dimensions that comprise the leader character framework considered essential for political leadership? How do voters actually assess the character of their current leaders? And do populist voters on the right dif- fer markedly in how they judge the character of political leaders? The next section explains our methodology and then presents the results in light of each specific research question.

\section{Methods}

We commissioned an opinion survey of voting-age individuals in the US, Canada, and the UK. We constructed a survey instrument (available from the authors upon request) that probed how voters engaged the leader character framework developed and validated by Crossan et al. (2016), and then employed the framework to assess specific aspects of character for political leaders in each of the three countries. We chose these countries 
because they are similar in terms of democratic development, main language, media freedom, and the key role played by political leaders in national politics.

We relied on the AskingCanadians organization and their affiliates to administer the opinion survey and collect the results. Respondents were sourced from a wellestablished online market research panel community. The total sample of 2,194 respondents contained nationally representative sub-samples of 629 Americans, 1,039 Canadians, and 526 Britons, all of voting age, who completed an online survey. The American and Canadian data were collected during the week of October 19-23, 2018 , or about three weeks prior to the mid-term elections in the US. Data collection in the UK took place during the week of November 19-23, 2018. The samples were measured against interlocking age, gender, and regional quota structures that resemble the demographic distribution of the three countries.

The nature of our research questions required identifying existing national political leaders. We focused on President Donald Trump, a Republican, and former president Barack Obama, a Democrat, in the US. We selected Liberal Party leader and prime minister, Justin Trudeau, as the key subject in Canada (the other two main Canadian party leaders were new in their positions; thus, most citizens had not yet had much opportunity to form impressions about the leaders' character). And, lastly, in the UK, we considered the then prime minister and leader of the Conservative Party, Theresa May; the then member of parliament and Conservative Boris Johnson; Labour Party leader, Jeremy Corbyn; leader of the UK Independence Party (UKIP), Gerard Batten; and leader of the Brexit Party, Nigel Farage. We believe that in each case of the leaders under study, respondents had ample opportunity to consider their respective leaders, become informed about them, and evaluate their character as a result of extensive proofing and exposure in the media.

\section{Results}

We first explore how citizens of voting-age adjudicate character in political leadership and then probe the role of a populist attitude in evaluating character.

\subsection{Does Character Matter? Are All Eleven Character Dimensions Considered Essential for Political Leadership?}

Good leadership is a function of competencies (skills, knowledge), character (virtues, values, personality traits), and the commitment to do the hard work of leadership (aspiration, engagement, sacrifice; Crossan et al., 2016; Gandz, Crossan, Seijts, \& Stephenson, 2010). Thus, we first asked respondents to force-choice or rank order the importance of competencies, character, and commitment as they relate to the role of prime minister or president $(1=$ most important; $3=$ least important).
The results revealed that character was ranked as the most important consideration by 30 (UK) to 40 percent (US) of respondents. Competencies was the most important consideration for 44 percent of respondents from the US and UK and for 47 percent of respondents from Canada. These results led us to conclude that character is an important consideration in the vote for political leaders across the populations under study.

We also explored whether all eleven character dimensions are considered important for adjudicating character, or whether citizens of voting-age value only a subset of these dimensions in the evaluation of leadership. If the latter, which dimensions are considered the most salient to adjudicating character? Thus, we asked respondents to rate each of the eleven character dimensions according to how strongly they agreed or disagreed that the dimension is an essential aspect for performing the role of prime minister or president. We provided a description of each character dimension as well as specific examples of behaviours in parentheses to enhance the clarity of the dimension. The scores ranged from 1 (not at all) to 5 (to a great extent); the midpoint of the scale was 3 (somewhat).

The results are shown in Table 2 and indicate that respondents across the three countries deemed all character dimensions to be essential in political leadership. Most of the character dimensions had a rating of 4 or higher; the lowest score (3.79) was for transcendence in the UK sample. The results in Table 2 also reveal a striking similarity in responses across the populations. The averages are high and similar, which may indicate that the character dimensions are equally valued across Canada, the UK, and the US. Accountability, integrity, judgement, and justice were rated highest, and humility and transcendence lowest.

\subsection{Evaluating the Character of Political Leaders}

We next asked respondents to employ the character framework to assess their political leaders. Respondents rated the extent to which they perceive their leaders to actually demonstrate the behaviours associated with each of the eleven character dimensions. The scores ranged from 1 (not at all) to 5 (to a great extent); the midpoint of the scale was 3 (somewhat). The results are shown in Table 3 and allow us to generate five important observations.

First, there is an appreciable gap between the perceived importance of the character dimensions as reported by the respondents (see Table 2) and whether the respondents believe their political leaders live up to these expectations (see Table 3). Second, in the US, respondents scored Obama higher than Trump on all character dimensions. The same pattern exists for Canada and the UK where respondents rated their national leaders higher than Trump on almost all character dimensions. Third, respondents evaluated Trudeau and Obama highest; the other leaders are evaluated lower on the 
Table 2. Means and standard deviations for the perceived importance of the dimensions of character for political leadership as rated by citizens of voting age.

\begin{tabular}{lccr}
\hline & Canada & US & UK \\
\hline Accountability & $4.39(1.02)$ & $4.46(0.85)$ & $4.22(0.93)$ \\
Collaboration & $4.12(0.93)$ & $4.21(0.88)$ & $3.96(0.92)$ \\
Courage & $3.99(0.93)$ & $4.23(0.88)$ & $4.11(0.90)$ \\
Drive & $4.15(0.90)$ & $4.30(0.85)$ & $4.11(0.93)$ \\
Humanity & $4.09(0.95)$ & $4.23(0.91)$ & $4.04(0.97)$ \\
Humility & $4.01(0.96)$ & $3.99(0.98)$ & $3.88(1.00)$ \\
Integrity & $4.42(0.96)$ & $4.48(0.84)$ & $4.24(0.97)$ \\
Judgment & $4.33(0.95)$ & $4.42(0.85)$ & $4.16(0.93)$ \\
Justice & $4.35(0.96)$ & $4.41(0.87)$ & $4.21(0.91)$ \\
Temperance & $4.07(0.93)$ & $4.17(0.93)$ & $4.05(0.93)$ \\
Transcendence & $3.92(0.95)$ & $4.02(0.89)$ & $3.79(0.94)$ \\
\hline
\end{tabular}

character dimensions. Fourth, the results indicate that Canadians and Britons consistently rated Trump as much less adept across all eleven character dimensions than did their American counterparts. Fifth, in the UK, the ratings that Trump received are much closer to those of populist leaders Johnson, Batten, and Farage than to those of May and Corbyn. May and Corbyn received ratings around the midpoint; the other leaders scored substantially lower on the character assessments.

\subsection{Populism and Its Connection to Character}

The third question we explored was whether respondents with a strong populist attitude appreciate the im-

Table 3. Means and standard deviations for the extent to which political leaders demonstrate the dimensions of character as rated by citizens of voting age.

\begin{tabular}{|c|c|c|c|c|c|c|c|c|c|c|}
\hline & \multicolumn{2}{|c|}{ US } & \multicolumn{2}{|c|}{ Canada } & \multicolumn{6}{|c|}{ UK } \\
\hline & Obama & Trump & Trudeau & Trump & May & Johnson & Corbyn & Batten & Farage & Trump \\
\hline Accountability & $\begin{array}{c}3.36 \\
(1.43)\end{array}$ & $\begin{array}{c}2.46 \\
(1.49)\end{array}$ & $\begin{array}{c}3.00 \\
(1.31)\end{array}$ & $\begin{array}{c}1.54 \\
(1.05)\end{array}$ & $\begin{array}{c}3.08 \\
(1.35)\end{array}$ & $\begin{array}{c}2.50 \\
(1.32)\end{array}$ & $\begin{array}{c}3.00 \\
(1.31)\end{array}$ & $\begin{array}{c}2.48 \\
(1.30)\end{array}$ & $\begin{array}{c}2.50 \\
(1.33)\end{array}$ & $\begin{array}{c}2.21 \\
(1.32)\end{array}$ \\
\hline Collaboration & $\begin{array}{c}3.57 \\
(1.35)\end{array}$ & $\begin{array}{c}2.45 \\
(1.36)\end{array}$ & $\begin{array}{c}3.41 \\
(1.25)\end{array}$ & $\begin{array}{c}1.47 \\
(0.90)\end{array}$ & $\begin{array}{c}2.96 \\
(1.32)\end{array}$ & $\begin{array}{c}2.53 \\
(1.28)\end{array}$ & $\begin{array}{c}2.98 \\
(1.33)\end{array}$ & $\begin{array}{c}2.43 \\
(1.27)\end{array}$ & $\begin{array}{c}2.40 \\
(1.25)\end{array}$ & $\begin{array}{c}2.00 \\
(1.27)\end{array}$ \\
\hline Courage & $\begin{array}{c}3.49 \\
(1.32)\end{array}$ & $\begin{array}{c}3.39 \\
(1.52)\end{array}$ & $\begin{array}{c}3.24 \\
(1.21)\end{array}$ & $\begin{array}{c}2.82 \\
(1.61)\end{array}$ & $\begin{array}{c}3.34 \\
(1.35)\end{array}$ & $\begin{array}{c}2.93 \\
(1.30)\end{array}$ & $\begin{array}{c}3.09 \\
(1.32)\end{array}$ & $\begin{array}{c}2.57 \\
(1.23)\end{array}$ & $\begin{array}{c}2.97 \\
(1.34)\end{array}$ & $\begin{array}{c}3.06 \\
(1.50)\end{array}$ \\
\hline Drive & $\begin{array}{c}3.64 \\
(1.26)\end{array}$ & $\begin{array}{c}3.58 \\
(1.42)\end{array}$ & $\begin{array}{c}3.40 \\
(1.20)\end{array}$ & $\begin{array}{c}2.76 \\
(1.50)\end{array}$ & $\begin{array}{c}3.29 \\
(1.32)\end{array}$ & $\begin{array}{c}3.12 \\
(1.31)\end{array}$ & $\begin{array}{c}3.17 \\
(1.28)\end{array}$ & $\begin{array}{c}2.73 \\
(1.26)\end{array}$ & $\begin{array}{c}3.08 \\
(1.32)\end{array}$ & $\begin{array}{c}3.22 \\
(1.44)\end{array}$ \\
\hline Humanity & $\begin{array}{c}3.81 \\
(1.29)\end{array}$ & $\begin{array}{c}2.37 \\
(1.38)\end{array}$ & $\begin{array}{c}3.70 \\
(1.22)\end{array}$ & $\begin{array}{c}1.39 \\
(0.83)\end{array}$ & $\begin{array}{c}2.93 \\
(1.29)\end{array}$ & $\begin{array}{c}2.50 \\
(1.25)\end{array}$ & $\begin{array}{c}3.22 \\
(1.33)\end{array}$ & $\begin{array}{c}2.47 \\
(1.28)\end{array}$ & $\begin{array}{c}2.36 \\
(1.22)\end{array}$ & $\begin{array}{c}1.92 \\
(1.23)\end{array}$ \\
\hline Humility & $\begin{array}{c}3.65 \\
(1.40)\end{array}$ & $\begin{array}{c}2.09 \\
(1.29)\end{array}$ & $\begin{array}{c}3.20 \\
(1.31)\end{array}$ & $\begin{array}{c}1.38 \\
(0.88)\end{array}$ & $\begin{array}{c}2.88 \\
(1.28)\end{array}$ & $\begin{array}{c}2.31 \\
(1.28)\end{array}$ & $\begin{array}{c}2.96 \\
(1.38)\end{array}$ & $\begin{array}{c}2.40 \\
(1.29)\end{array}$ & $\begin{array}{c}2.29 \\
(1.27)\end{array}$ & $\begin{array}{c}1.81 \\
(1.24)\end{array}$ \\
\hline Integrity & $\begin{array}{c}3.52 \\
(1.47)\end{array}$ & $\begin{array}{c}2.54 \\
(1.52)\end{array}$ & $\begin{array}{c}3.07 \\
(1.32)\end{array}$ & $\begin{array}{c}1.61 \\
(1.11)\end{array}$ & $\begin{array}{c}3.05 \\
(1.35)\end{array}$ & $\begin{array}{c}2.56 \\
(1.34)\end{array}$ & $\begin{array}{c}3.08 \\
(1.34)\end{array}$ & $\begin{array}{c}2.56 \\
(1.34)\end{array}$ & $\begin{array}{c}2.64 \\
(1.35)\end{array}$ & $\begin{array}{c}2.21 \\
(1.38)\end{array}$ \\
\hline Judgment & $\begin{array}{c}3.64 \\
(1.30)\end{array}$ & $\begin{array}{c}2.84 \\
(1.52)\end{array}$ & $\begin{array}{c}3.12 \\
(1.27)\end{array}$ & $\begin{array}{c}1.76 \\
(1.21)\end{array}$ & $\begin{array}{c}3.12 \\
(1.28)\end{array}$ & $\begin{array}{c}2.75 \\
(1.29)\end{array}$ & $\begin{array}{c}2.97 \\
(1.31)\end{array}$ & $\begin{array}{c}2.54 \\
(1.32)\end{array}$ & $\begin{array}{c}2.69 \\
(1.31)\end{array}$ & $\begin{array}{c}2.42 \\
(1.40)\end{array}$ \\
\hline Justice & $\begin{array}{c}3.58 \\
(1.35)\end{array}$ & $\begin{array}{c}2.60 \\
(1.47)\end{array}$ & $\begin{array}{c}3.25 \\
(1.29)\end{array}$ & $\begin{array}{c}1.53 \\
(0.97)\end{array}$ & $\begin{array}{c}3.01 \\
(1.32)\end{array}$ & $\begin{array}{c}2.63 \\
(1.31)\end{array}$ & $\begin{array}{c}3.24 \\
(1.33)\end{array}$ & $\begin{array}{c}2.52 \\
(1.30)\end{array}$ & $\begin{array}{c}2.50 \\
(1.30)\end{array}$ & $\begin{array}{c}2.08 \\
(1.33)\end{array}$ \\
\hline Temperance & $\begin{array}{c}4.06 \\
(1.19)\end{array}$ & $\begin{array}{c}2.16 \\
(1.24)\end{array}$ & $\begin{array}{c}3.69 \\
(1.19)\end{array}$ & $\begin{array}{c}1.40 \\
(0.83)\end{array}$ & $\begin{array}{c}3.45 \\
(1.26)\end{array}$ & $\begin{array}{c}2.55 \\
(1.24)\end{array}$ & $\begin{array}{c}3.22 \\
(1.31)\end{array}$ & $\begin{array}{c}2.55 \\
(1.29)\end{array}$ & $\begin{array}{c}2.58 \\
(1.27)\end{array}$ & $\begin{array}{c}2.01 \\
(1.30)\end{array}$ \\
\hline Transcendence & $\begin{array}{c}3.60 \\
(1.32)\end{array}$ & $\begin{array}{c}2.88 \\
(1.47)\end{array}$ & $\begin{array}{c}3.42 \\
(1.24)\end{array}$ & $\begin{array}{c}1.85 \\
(1.20)\end{array}$ & $\begin{array}{c}2.98 \\
(1.35)\end{array}$ & $\begin{array}{c}2.72 \\
(1.29)\end{array}$ & $\begin{array}{c}3.03 \\
(1.32)\end{array}$ & $\begin{array}{c}2.51 \\
(1.29)\end{array}$ & $\begin{array}{c}2.60 \\
(1.31)\end{array}$ & $\begin{array}{c}2.46 \\
(1.37)\end{array}$ \\
\hline Overall & $\begin{array}{c}3.62 \\
(1.21)\end{array}$ & $\begin{array}{c}2.65 \\
(1.26)\end{array}$ & $\begin{array}{c}3.31 \\
(1.10)\end{array}$ & $\begin{array}{c}1.74 \\
(0.86)\end{array}$ & $\begin{array}{c}3.10 \\
(1.14)\end{array}$ & $\begin{array}{c}2.64 \\
(1.09)\end{array}$ & $\begin{array}{c}3.08 \\
(1.15)\end{array}$ & $\begin{array}{c}2.52 \\
(1.14)\end{array}$ & $\begin{array}{c}2.58 \\
(1.09)\end{array}$ & $\begin{array}{c}2.29 \\
(1.10)\end{array}$ \\
\hline
\end{tabular}


portance of character in leadership and, if so, which specific dimensions of character are considered especially important by those with a strong populist attitude. A populist attitude has been described as one that includes a key feature: authoritarianism. Inglehart and Norris (2016) explained that individuals with authoritarian leanings favour the personal power exerted by a strong leader, which is thought to reflect the will of the people. We used two items taken from round six of the World Values Survey to assess authoritarianism. A sample item is:

There are various types of political systems. For each one, would you say it is a very good, fairly good, fairly bad, or very bad way of governing the United Kingdom? Having a strong leader who does not have to bother with parliament and elections. (Inglehart et al., 2014, p. 9)

The response options included very good (1); fairly good (2); fairly bad (3); and very bad (4). The average scores of the two items were $2.95(S D=0.93)$ for the UK; 3.17 (SD = 0.84) for the US; and $3.43(S D=0.69)$ for Canada. These results appear to be consistent with the marked absence of populist politics at the national level in Canada as compared to the UK and the US.

The results showed that the correlation between a populist attitude as self-identified by the respondents and the belief that character is the most important aspect of political leadership was negative and significant for respondents from the UK $(r=-.15, p<.001)$ and the US $(r=-.14, p<.001)$ and not significant for respondents from Canada $(r=-.05, p>.05)$. In other words, respondents from the UK and the US with a strong populist attitude (or authoritarian leanings) were less inclined to rank-order character (in relation to competencies and commitment) as their most important consideration for performing the role of prime minister or president. Although the magnitude of the correlations is small (see Cohen, 1992), the results for the data from the US and UK are significant and suggest, as we describe in subsequent sections, that populists care less about character than non-populists.

We then explored whether there are differences in the way a populist attitude is related to the evaluation of the perceived importance of each of the eleven character dimensions for performing the role of prime minister or president. The results are shown in Table 4. The data suggest that Americans and Canadians who score high on the populist attitude believe all the character dimensions are less essential to the role of prime minister or president as compared to individuals who score low on the populist attitude. The results are less clear for the respondents from the UK. Table 4 also indicates that, remarkably, the most consistent results across the three countries are for the dimensions of accountability, integrity, judgment, and justice-the dimensions of character that individuals generally see as most important for political leadership (see Table 2). Again, these results seem to indicate that populists care less than non-populists about character in political leadership.

\subsection{What Drives Evaluations of Character?}

Our assumption is that a host of variables may drive evaluations of character in political leaders. For example, it is likely that political affiliation influences the perceived character of leaders. Supporters of the Conservative Party may prefer May's character more so than nonConservative voters. Further, annual income was included as a potential predictor because economic distress may motivate individuals to vote for Trump or other populist leaders. Thus, the final question we explored in our study was which demographic, social-economic, and political preference variables contribute to the prediction of character. We were particularly interested in whether a populist attitude explains variance in character over and above a myriad of demographic, socialeconomic, and political preference variables.

Table 4. Correlations between a populist attitude and dimensions of character.

\begin{tabular}{llll}
\hline & Canada & US & UK \\
\hline Accountability & $.17^{* * *}$ & $.17^{* * *}$ & $.12^{* *}$ \\
Collaboration & $.21^{* * *}$ & $.14^{* * *}$ & .06 \\
Courage & $.11^{*}$ & $.10^{*}$ & .02 \\
Drive & $.19^{* * *}$ & $.08^{*}$ & .07 \\
Humanity & $.17^{* * *}$ & $.11^{* *}$ & .02 \\
Humility & $.12^{* *}$ & $.10^{*}$ & -.05 \\
Integrity & $.24^{* * *}$ & $.21^{* * *}$ & $.21^{* * *}$ \\
Judgment & $.21^{* * *}$ & $.21^{* * *}$ & $.19^{* * *}$ \\
Justice & $.22^{* * *}$ & $.14^{* * *}$ & $.13^{* *}$ \\
Temperance & $.16^{* * *}$ & $.10^{*}$ & .03 \\
Transcendence & $.09^{*}$ & .02 & -.08 \\
\hline
\end{tabular}

Notes: Scale scores for populist attitude are reverse coded such that respondents who score high on the populist attitude believe the character dimensions matter less in political leadership as compared to individuals who score low on the populist attitude. ${ }^{*} p<.05$; $* * \mathrm{p}<.01 ; * * * \mathrm{p}<.001$. 
We used stepwise multiple regression to determine which variables drive preferences in character, and we combined the eleven dimensions of character into a single scale score. We entered demographic, socialeconomic, and political preference variables in step 1 and then explored whether a populist attitude added any incremental variance in step 2 . Any incremental variance explained would provide more robust support for the relationship between a populist attitude and the evaluation of character in political leadership. The results are shown in Tables 5, 6, and 7; these findings allow us to generate three important observations.

First, demographic, social-economic, and political preference variables contribute unique and significant variance to the evaluation of character in political leaders. However, the results, as can be expected, depend on the political leader. For example, age and gender were significant predictors for Obama and assessments of his character (see Table 6, step 2). In contrast, voters from small cities, towns, and rural areas were significant predictors for Trump and his character (see Table 6, step 2). Second, political affiliation or preference was a robust predictor for all political leaders in all three countries, and in the expected direction. For example, Liberals evaluate Trudeau's character higher than non-Liberals (see Table 5, step 2). Third, and most important, the results reinforce our earlier findings regarding the influence of a populist attitude on the evaluation of character. This is because a populist attitude predicted significant vari- ance in character over and above the baseline model that included the demographic, social-economic, and political preference variables, as shown by the significant $\Delta R^{2}$ in step 2.

The results of the regression analyses suggest holding a strong populist attitude has a positive effect on the assessment of the character of populist leaders (Trump, Johnson, Batten; and, perhaps somewhat surprisingly, May) and a negative effect on non-populist leaders (Trudeau, Obama). That is, respondents who hold a less populist attitude rate the character of Trudeau and Obama higher than do respondents who hold a strong populist attitude (see Tables 5 and 6). In contrast, respondents who hold a strong populist attitude rate the character of Trump, Johnson, Batten, and May higher than do respondents who hold a less populist attitude (see Tables 6 and 7).

We converted the $\Delta R 2$ to an effect size or $f^{2}$ (see Cohen, 1992). The magnitude of the effect for a populist attitude ranges from small to medium (see Tables 5, 6, and 7). Effect sizes between .01 and .15 are considered small; between .15 and .35 are considered medium; and effect sizes above .35 are considered large.

\section{Conclusion}

The foundation of good leadership is character in addition to competencies and commitment. The results of our study reveal that, generally speaking, character in po-

Table 5. Results of stepwise hierarchical regression predicting character by citizens of voting age in Canada.

\begin{tabular}{|c|c|c|c|c|c|}
\hline & \multicolumn{5}{|c|}{ Trudeau } \\
\hline & $\Delta R^{2}$ & $f^{2}$ & B & SE & $\beta$ \\
\hline \multicolumn{6}{|l|}{ Step 1} \\
\hline Gender & & & .22 & .09 & $.11^{*}$ \\
\hline Age & & & .09 & .06 & .07 \\
\hline Political orientation & & & 1.02 & .09 & $.51 * * *$ \\
\hline Income & & & -.17 & .10 & $-.08+$ \\
\hline Education & & & .01 & .10 & .01 \\
\hline Rural & & & .11 & .10 & .05 \\
\hline \multirow[t]{2}{*}{ Born in Canada } & & & .09 & .12 & .04 \\
\hline & $.30 * * *$ & .43 & & & \\
\hline \multicolumn{6}{|l|}{ Step 2} \\
\hline Gender & & & .20 & .09 & $.10^{*}$ \\
\hline Age & & & .05 & .06 & .04 \\
\hline Political orientation & & & 1.01 & .09 & $.51 * * *$ \\
\hline Income & & & -.19 & .10 & $-.09 \dagger$ \\
\hline Education & & & -.01 & .10 & -.01 \\
\hline Rural & & & .09 & .10 & .04 \\
\hline Born in Canada & & & .16 & .12 & .07 \\
\hline \multirow[t]{2}{*}{ Populist attitude } & & & .17 & .07 & $.12^{*}$ \\
\hline & $.01 *$ & .01 & & & \\
\hline
\end{tabular}

Notes: Gender: 1 = Female; $0=$ Male; Political orientation: $1=$ Liberal; $0=$ other; Income: $1=>$ CA $\$ 75,000 ; 0=\leq$ CA $\$ 74,999 ;$ Education: 1 = bachelors, and post-graduate; $0=$ less than high school, high school, and some college or university; Rural: $1=$ downtown area of major city or surrounding neighbourhood, and suburbs of major city; $0=$ rural municipality, small town or village, and small city or large town; and Born in Canada: $1=$ No; $0=$ Yes. Scale scores for populist attitude are reverse coded. $\dagger<.10 ; *^{*}<.05 ; * * * p<.001$. 
Table 6. Results of stepwise hierarchical regression predicting character by citizens of voting age in the US.

\begin{tabular}{|c|c|c|c|c|c|c|c|c|c|c|}
\hline & \multicolumn{5}{|c|}{ Trump } & \multicolumn{5}{|c|}{ Obama } \\
\hline & $\Delta R^{2}$ & $f^{2}$ & B & $\mathrm{SE}$ & $\beta$ & $\Delta \mathrm{R}^{2}$ & $f^{2}$ & B & $\mathrm{SE}$ & $\beta$ \\
\hline \multicolumn{11}{|l|}{ Step 1} \\
\hline Gender & & & -.09 & .09 & -.04 & & & .25 & .09 & $.11^{* *}$ \\
\hline Age & & & -.03 & .06 & -.02 & & & -.20 & .05 & $-.13^{* * *}$ \\
\hline Political orientation & & & 1.61 & .09 & $.61 * * *$ & & & 1.43 & .09 & $.58 * * *$ \\
\hline Income & & & -.07 & .10 & -.03 & & & -.05 & .09 & -.02 \\
\hline Education & & & -.17 & .09 & $-.07 \dagger$ & & & .13 & .09 & .06 \\
\hline Rural & & & -.17 & .09 & $-.07 \dagger$ & & & .15 & .09 & $.06+$ \\
\hline \multirow[t]{2}{*}{ Born in US } & & & .22 & .19 & .04 & & & .26 & .18 & .05 \\
\hline & $.39 * * *$ & .64 & & & & $.40 * * *$ & .67 & & & \\
\hline \multicolumn{11}{|l|}{ Step 2} \\
\hline Gender & & & -.08 & .09 & -.03 & & & .26 & .08 & $.11 * *$ \\
\hline Age & & & .06 & .06 & .04 & & & -.24 & .05 & $-.16 * * *$ \\
\hline Political orientation & & & 1.46 & .09 & $.56 * * *$ & & & 1.38 & .09 & $.56 * * *$ \\
\hline Income & & & -.08 & .09 & -.03 & & & -.04 & .09 & -.02 \\
\hline Education & & & -.04 & .09 & -.02 & & & .06 & .09 & .03 \\
\hline Rural & & & -.21 & .09 & $-.08 *$ & & & .17 & .09 & $.07^{*}$ \\
\hline Born in US & & & .13 & .18 & .02 & & & .31 & .18 & $.06 \dagger$ \\
\hline \multirow[t]{2}{*}{ Populist attitude } & & & -.40 & .06 & $-.26 * * *$ & & & .21 & .05 & $.14^{* * *}$ \\
\hline & $.06 * * *$ & .06 & & & & $.02 * * *$ & .02 & & & \\
\hline
\end{tabular}

Notes: Gender: 1 = Female; $0=$ Male; Trump-Political orientation: $1=$ Republican; $0=$ other; Obama-Political orientation: $1=$ Democrat; $0=$ other; Income: $1=$ > US \$50,000; $0=\leq$ US \$49,999; Education: $1=$ bachelors, and post-graduate; $0=$ less than high school, high school, and some college or university; Rural: 1 = downtown area of major city or surrounding neighbourhood, and suburbs of major city; $0=$ rural municipality, small town or village, and small city or large town; and Born in US: $1=$ No; $0=$ Yes. Scale scores for populist attitude are reverse coded. $\dagger<.10 ;{ }^{*} p<.05 ; * * p<.01 ; * * * p<.001$.

litical leaders matters to citizens of voting age in Canada, the US, and the UK. Further, there was a striking similarity among respondents from the three countries concerning the perceived importance of the eleven character dimensions in political leadership. The results also reveal that there is a noticeable, indeed disturbing, gap between the perceived importance of the character dimensions and how the political leaders under investigation measure up: they don't, hence the character deficit in leadership.

However, among the most interesting results of our study is the finding that individuals who have a strong populist attitude appear to care less about character in political leadership; they are less likely to identify character as their most important consideration in their vote for prime minister or president. And again, generally speaking, those who have a strong populist attitude tend to agree less that the eleven character dimensions are essential to the role of prime minister or president. The effects for populism were robust: a populist attitude contributed to the prediction of character even after including a myriad of demographic, social-economic, and political preference variables in regression analyses. These findings bolster our assertion that citizens of voting age who subscribe to populism carry different views of character than the general voting public. These findings are important because they add to our general understanding of the factors that influence vote choice and to the extant research that reports that some voters pay greater attention to leader characteristics than others (Bakker et al., 2016; Blais, 2011, p. 7).

In summary, the results of our study suggest the leader character framework we employed is useful for studying how people think about leader character. We conclude this rich and integrated framework has utility across national populations, at least with respect to the three Anglo-American countries studied. Second, we note that the populist and non-populist voters in each country possess markedly different attitudes about character. These differences seem durable despite the presence of other factors such as socio-economic status. Populist voters generally think character matters less than non-populist voters and yet are more positive about the character of populist leaders like Trump and Johnson.

The effects we obtained were small to moderate yet consistent across analyses. While certainly more indepth follow-up of our findings ought to be pursued, our work informs efforts to understand how voters think about leaders. As well, our findings reflect work by scholars such as Bakker et al. (2016) who report that a populist voter's psychological orientation explains their attraction to particular leaders. Our data clearly show that populist voters are different than non-populists in how they judge the character of political leaders. While many authors such as Mudde (2017) have observed that leaders are important with respect to understanding the emergence of populism, our work contributes by probing exactly how 
Table 7. Results of stepwise hierarchical regression predicting character by citizens of voting age in the UK.

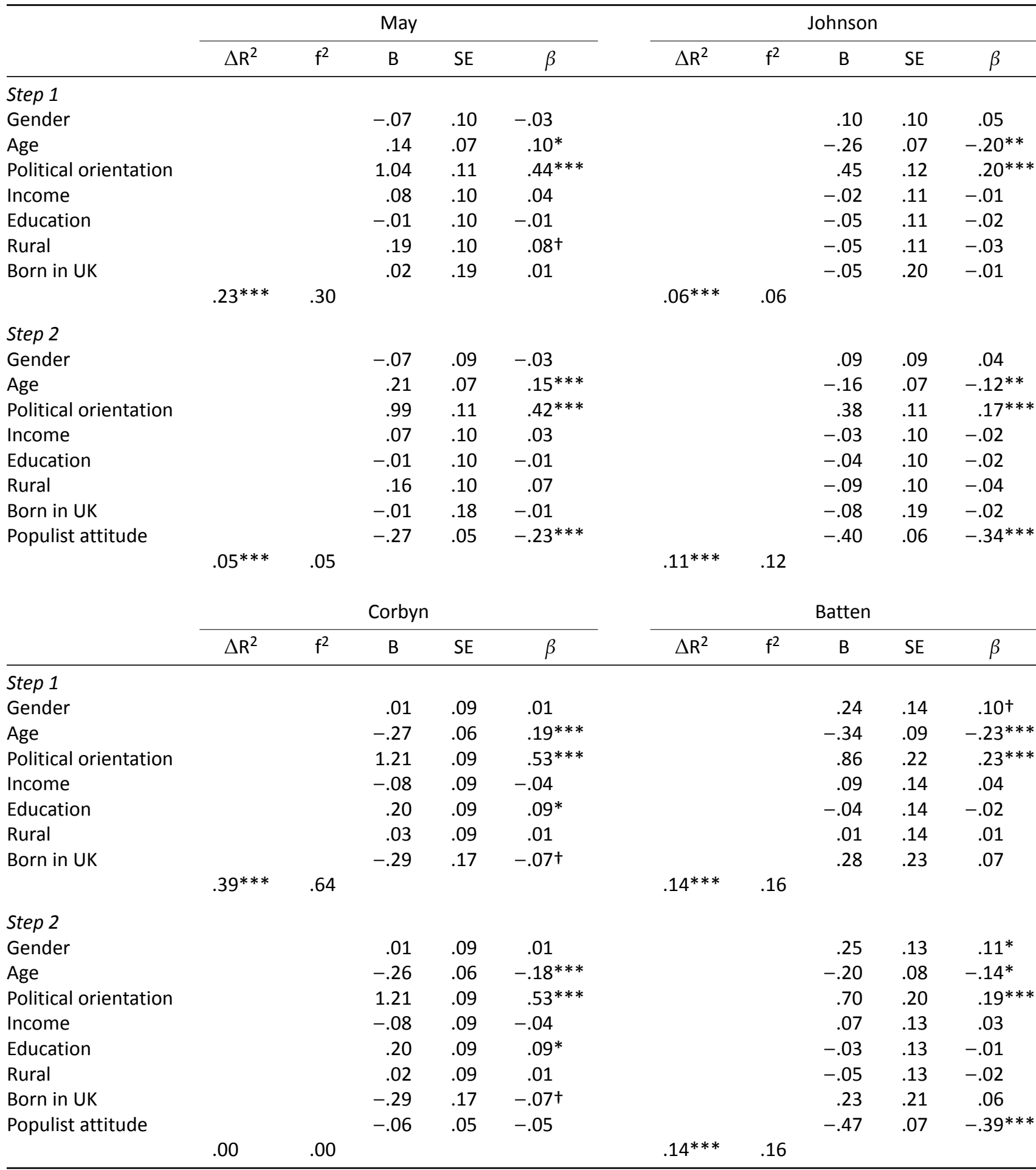

Notes: Gender: 1 = Female; 0 = Male; May-Political orientation: 1 = Conservative; 0 = other; Johnson-Political orientation: $1=$ Conservative; $0=$ other; Corbyn - Political orientation: $1=$ Labour; $0=$ other; Batten-Political orientation: $1=$ UKIP; $0=$ other; Income: $1=>\mathrm{GB} £ 26,000 ; 0=\leq \mathrm{GB} £ 25$,999; Education: 1 = Higher National Certificate or higher; $0=\mathrm{GCSE}$, and A/AS level; Rural: 1 = downtown area of major city or surrounding neighbourhood, and suburbs of major city; $0=$ rural municipality, small town or village, and small city or large town; and Born in UK: $1=$ No; $0=$ Yes. Scale scores for populist attitude are reverse coded. $+<.10 ;{ }^{*} p<.05$; $* * \mathrm{p}<.01 ; * * * \mathrm{p}<.001$.

populists think about character, and its eleven interrelated dimensions, when adjudicating political leaders.

Our results must be interpreted with caution given the limitations associated with our research method.
Online opinion poll sampling is a common approach to probe public opinion. However, the approach is necessarily limited for at least three reasons. First, we did not sample the entire population; instead, we used relatively 
small sample sizes. Second, it is possible that there are biases embedded in our data; for example, we cannot rule out that the more educated or high-status individuals responded more frequently to the survey. Third, public opinion is likely to change across time. As a result, we cannot say with certainty that the results we obtained would necessarily be replicated with a different sample at another time. Further, our measures were limited in scope. For example, populist attitude was measured by two items. Also, we did not examine the actual electoral impact of perceptions of character of political leaders. As well, we focused on three Anglo-American countries; it is important to study leadership and populism across other nations on different continents to assess the generalizability of our findings.

\section{Acknowledgments}

We gratefully acknowledge the financial support of the Ian O. Ihnatowycz Institute for Leadership at the Ivey Business School as well as the insightful comments of three anonymous reviewers and the editorial team at Cogitatio.

\section{Conflict of Interests}

The authors declare no conflict of interests.

\section{References}

Aarts, K., Blais, A., \& Schmitt, H. (2011). Political leaders and democratic elections. Oxford: Oxford University Press.

Bakker, B., Rooduijn, M., \& Schumacher, G. (2016). The psychological roots of populist voting: Evidence from the United States, the Netherlands, and Germany. European Journal of Political Research, 55(2), 302-320.

Ballard, E. J., \& Suedfeld, P. (1988). Performance ratings of Canadian prime ministers: Individual and situational factors. Political Psychology, 9(2), 291-302.

Barber, J. D. (1972). The presidential character: Predicting performance in the White House. Englewood Cliffs, NJ: Prentice Hall.

Bartle, J., \& Crewe, I. (2002). The impact of party leaders in Britain. In A. King (Ed.), Leaders' personalities and the outcomes of democratic elections (pp. 70-95). New York, NY: Oxford University Press.

Beck, M., \& Nadeau, R. (2015). Between leadership and charisma: The importance of leaders. In M. Costa Lobo \& J. Curtice (Eds.), The role of leader evaluations in democratic elections (pp. 169-189). Oxford: Oxford University Press.

Bennister, M. (2008). Blair and Howard: Predominant prime ministers compared. Parliamentary Affairs, 61(2), 334-355.

Bittner, A. (2011). Platform or personality? The role of party leaders in elections. New York, NY: Oxford University Press.
Blais, A. (2011). Political leaders and democratic elections. In K. Aarts, A. Blais, \& H. Schmitt (Eds.), Political leaders and democratic elections (pp. 11-34). Oxford: Oxford University Press.

Bos, L., Sheets, P., \& Boomgaarden, H. (2018). The role of implicit attitudes in populist-right support. Political Psychology, 39(1), 69-87.

Byrne, A., Crossan, M., \& Seijts, G. (2018). The development of leader character through crucible moments. Journal of Management Education, 42(2), 265-293.

Canadian Election Study. (2015). Surveys: 2015. Canadian Election Study. Retrieved from https://ces-eec. arts.ubc.ca/english-section/surveys

Clarke, H., Kornberg, A., MacLeod, J., \& Scotto, T. (2005). Too close to call: Political choice in Canada, 2004. PS: Political Science and Politics, 38(2), 247-253.

Cohen, J. (1992). A power primer. Psychological Bulletin, 112(1), 155-159.

Costa Lobo, M., \& Curtice, J. (Eds.). (2015). The role of leader evaluations in democratic elections. Oxford: Oxford University Press.

Courtney, J. (1976). Prime ministerial character: An examination of Mackenzie King's political leadership. Canadian Journal of Political Science, 9(1), 77-100.

Crossan, M., Byrne, A., Seijts, G., Reno, M., Monzani, L., \& Gandz, J. (2017). Toward a framework of leader character in organizations. Journal of Management Studies, 54(7), 986-1018.

Crossan, M., Seijts, G., \& Gandz, J. (2016). Developing leadership character. New York, NY: Routledge.

de la Torre, C. (2017). Populism in Latin America. In C. Kaltwasser, P. Taggart, P. Ochoa Espejo, \& P. Ostiguy (Eds.), The Oxford handbook of populism. Oxford: Oxford University Press. Retrieved from https://www.oxfordhandbooks.com/view/10.1093/ oxfordhb/9780198803560.001.0001/oxfordhb9780198803560-e-8

Dingfelder, S. (2004). A presidential personality: Intelligence and achievement-striving-But not straightforwardness-May predict the newly elected president's effectiveness. Monitor on Psychology, 35(10), 26.

Gandz, J., Crossan, M., Seijts, G., \& Stephenson, C. (2010). Leadership on trial: A manifesto for leadership development. London: Richard Ivey School of Business.

Garzia, D. (2011). The personalization of politics in western democracies: Causes and consequences on leader-follower relations. Leadership Quarterly, 22(4), 697-709.

Greenstein, F. (1975). Personality and politics: Problems of evidence, inference, and conceptualization. New York, NY: Norton.

Hinck, E. (1993). Enacting the presidency: Political argument, presidential debates, and presidential character. Santa Barbara, CA: Praeger.

Inglehart, R., Haerpfer, C., Moreno, A., Welzel, C., Kizilova, K., Diez-Medrano, J., . . . Purane, B. (Eds.). (2014). World values survey. Round six: Country- 
pooled datafile version. Madrid: JD Systems Institute. Retrieved from www.worldvaluessurvey.org/ WVSDocumentationWV6.jsp

Inglehart, R., \& Norris, P. (2016). Trump, Brexit and the rise of populism: Economic have-nots and cultural backlash (HKS Working Paper No. RWP16-026). Cambridge, MA: Harvard Kennedy School. Retrieved from https://research.hks.harvard.edu/publications/ workingpapers/Index.aspx

Johnston, R. (2002). Prime ministerial contenders in Canada. In A. King (Ed.), Leaders' personalities and the outcomes of democratic elections (pp. 158-193). New York, NY: Oxford University Press.

Johnston, R., Hartman, T., \& Pattie, C. (2019). Feelings about party leaders as a voter's heuristic: What happens when the leaders change? A note. Electoral Studies, 29, 164-170.

Kinder, D., Peters, M., Abelson, R., \& Fiske, S. (1980). Presidential prototypes. Political Behavior, 2(4), 315-337.

King, A. (2002). Do leaders' personalities really matter? In A. King (Ed.), Leaders' personalities and the outcomes of democratic elections (pp. 1-43). New York, NY: Oxford University Press.

Mansfield, S. (2004). Character and the greatness of Winston Churchill: Hero in a time of crisis. St. Albans: Cumberland House Publishing.

Meret, S. (2015). Charismatic female leadership and gender: Pia Kjaersgaard and the Danish People's Party. Patterns of Prejudice, 49(1/2), 81-102.

Miller, W. E., \& Shanks, J. M. (1996). The new American voter. Cambridge, MA: Harvard University Press.

Mudde, C. (2013). Three decades of populist radical right parties in western Europe: So what? European Journal of Political Research, 52(1), 1-19.

Mudde, C. (2017). Populism: A very short introduction. New York, NY: Oxford University Press.

Muis, J. (2015). The rise and demise of the Dutch extreme right: Discursive opportunities and support for the center democrats in the 1990s. Mobilization: An International Quarterly, 20(1), 41-60.

Nadeau, R., \& Blais, A. (1995). Economic conditions, leader evaluations and election outcomes in Canada. Canadian Public Policy, 21(2), 212-218.

Pfiffner, J. (2003). Judging presidential character. Public Integrity, 5(1), 7-24.

Seijts, G., Byrne, A., Crossan, M., \& Gandz, J. (2019). Leader character in board governance. Journal of Management and Governance, 23(1), 227-258.

Stockemer, D., \& Barisione, M. (2017). The 'new' discourse of the front national under Marine Le Pen: A slight change with a big impact. European Journal of Communication, 32(2), 100-115.

Theakston, K. (2011). Gordon Brown as prime minister: Political skills and leadership style. British Politics, 6(1), 78-100.

van den Pas, D., de Vries, C., \& van den Brug, W. (2011). A leader without a party: Exploring the relationship between Geert Wilders' leadership performance in the media and his electoral success. Party Politics, 19(3), 458-476.

Wright, T. A., \& Huang, C. (2008). Character in the organizational research: Past directions and future prospects. Journal of Organizational Behavior, 29(7), 981-987.

\section{About the Authors}

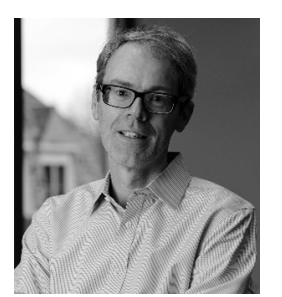

Gerard Seijts is Professor of organizational behavior and the Executive Director of the Ian $\mathrm{O}$. Ihnatowycz Institute for Leadership at the Ivey Business School at Western University in London, Canada. His research interests include leadership and organizational change. He is the recipient of awards for research, teaching, and outreach activities, and the author of several books, including Good Leaders Learn: Lessons from Lifetimes of Leadership (2013); Developing Leadership Character (2016); and Leadership in Practice: Theory and Cases in Leadership Character (2017).

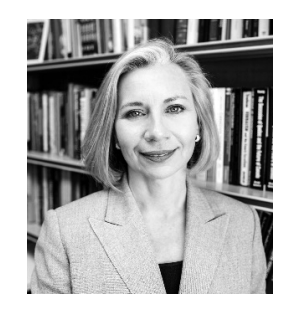

Cristine de Clercy is an Associate Professor in political science and Director of the Leadership and Democracy Laboratory at Western University in London, Canada. Dr. de Clercy specializes in comparative and Canadian politics. She studies leadership in politics and business, how political leaders address uncertainty, and how voters perceive leader character. 